\title{
Interpretace a přístup sociálních pracovníků ke standardům kvality sociálních služeb z hlediska lidských práv Markéta Elichová, Anna Sýkorová
}

Pomoc znevýhodněnému je v našem prostředí demokratické společnosti poskytována obecným uznáním základních lidských práv. Od tohoto uznání se odvijí všechny následné formy konkrétní pomoci. Lidská práva jsou tedy pro sociální práci klíčová. Sociální práce stojí na ideji univerzálních lidských práv, kłerá jsou uvedena v mezinárodních právních dokumentech (např. mezinárodní úmluvy o lidských právech, které ČR ratifikovala') a národních právních dokumentech. ${ }^{2}$ Od uznání univerzálních lidských práv se odvijí veškerá sociální práce v rưzných typech sociálních služeb jako konkrétní forma pomoci. Poskytovatelé sociálních služeb musí mít vždy na zřeteli základní lidská práva uživatelů, protože je to významné východisko jejich práce, jak potvrzuje Dobrovolný evropský rámec pro kvalitu sociálních služeb, který uvádí, že sociální služby, které podporují jedince společensky znevýhodněné s cílem zlepšit kvalitu jejich života a $\vee$ maximální mir̃e je začlenit do společnosti, ${ }^{3}$ udržet si nebo znovu nabýt své místo v komunitě, ve většinové společnosti, ve svém přirozeném společenství, ${ }^{4}$ jsou klíčovými nástroji pro zabezpečení základních lidských práv a lidské důstojnosti. ${ }^{5}$

Garantem dodržování lidských práv v zařizeních, kłerá poskytují sociální služby, je stát. Zajištuje to formou kontrol a přidělování licencí. ${ }^{6}$ Po roce 1989 vzniká vyšší potřeba respektovat lidská práva a důstojnost uživatelů sociálních služeb, což byla do té doby zanedbávaná oblasł zájmu. S tím související potřeba kontroly nad kvalitou poskytování sociálních služeb a nad dodržováním lidských práv byla hlavním dưvodem vzniku standardů kvality sociálních služeb.?

V roce 2002 vydalo Ministerstvo práce a sociálních věcí ČR (dále MPSV ČR) obecnou metodiku pro zavádění standardů kvality sociálních služeb (dále SQSS) do praxe. Na tvorbě standardů se podíleli zástupci odborné veřejnosti, poskytovatelé i uživatelé sociálních služeb. Zavedení standardů do organizací bylo dobrovolné. Současně probíhalo testování platnosti standardů a metodiky jejich kontroly u poskytovatelů. Standardy byly porovnávány se standardy kvality sociálních služeb některých evropských zemí a zahrnovaly také principy tradičních systémů zajištění kvality služeb. $\vee$ rámci česko-britského projektu proběhly v roce 2002 dobrovolné pilotní inspekce v rưzných zařizeních sociálních služeb. ${ }^{8}$ V roce 2007 vešel v platnost zákon č. 108/2006 Sb., o sociálních

\footnotetext{
1 Mezi nejdůležitější patří Listina základních práv a svobod, Mezinárodní pakt o občanských a politických právech, Mezinárodní pakt o hospodářských, sociálních a kulturních právech, Evropská úmluva o ochraně lidských práv a základních svobod, Všeobecná deklarace lidských práv.

2 Srov. Oldřich MATOUŠEK a kol., Encyklopedie sociální práce, Praha: Portál, 2013, s. 158-160.

3 Srov. Oldřich MATOUŠEK, Sociální služby: legislativa, ekonomika, plánování, hodnocení, Praha: Portál, 2011, s. 9-10.

4 Srov. MPSV ČR, Bílá kniha v sociálních službách, konzultační dokument, MPSV, 2003, s. 8. Dostupné na: http://www.mpsv.cz/files/ clanky/736/bila_kniha.pdf, citováno dne 16.11. 2013.

5 Srov. MPSV ČR, Dobrovolný evropský rámec pro kvalitu sociálních služeb, Výbor pro sociální ochranu, 10. 8. 2010, s. 4. Dostupné na: http:// www.mpsv.cz/files/clanky/10768/QF_document_100707_CZ_korekce.pdf, citováno dne 16. 11. 2013.

6 Srov. Oldřich MATOUŠEK, Sociální služby: legislativa, ekonomika, plánování, hodnocení, s. 11.

7 Srov. Pavel ČÁMSKÝ - Jan SEMBDNER - Dagmar KRUTILOVÁ, Sociální služby v ČR v teorii a praxi, Praha: Portál, 2011, s. 17.

8 Srov. Jaroslava SÝKOROVÁ a kol., Standardy kvality sociálních služeb: metodika pro zavádění standardu kvality sociálních služeb č. 2 - Ochrana práv uživatelů sociálních služeb v pobytových zařizeních pro seniory. Aplikační př́ručka pro poskytovatele, uživatele a zřizovatele, Praha: Č́eský helsinský
} 
službách, který zásadně změnil príistup k SQSS, když mezi povinnosti poskytovatelů sociálních služeb prímo zařadil dodržování standardů kvality sociálních služeb. V současné době jsou standardy kvality sociálních služeb souborem měřitelných a ověritelných kritérií, jejichž smyslem je umožnit průkazným způsobem posoudit kvalitu poskytované služby. ${ }^{9}$

Sociální služby mají pomoci těm, kteři nemají rovné přiležitosti. Takło znevýhodněným lidem sociální služby pomáhají vyrovnávat vlastní šance na společenské uplatnění, ${ }^{10}$ „,protože každý člověk má jako jednotlivec hodnotu, kterou nelze odvodit z jeho postavení a zásluh"." Tento praktický projev étosu sociální práce, tedy služba, solidarita, osvobozování a angažovanost pro chudé a slabé má velmi silnou spojitost s křestanstvím a jeho pojetím služby bližním. ${ }^{12}$ „V nové podobě zde máme před sebou křesfanskou premisu - všichni lidé jsou stvoření Boží, před tváríi Boha jsou si rovni a každý je každému bližním. Imperativ solidarity nemá v soudobém západním právu, stejně jako v křestanství, výjimku." "13 Solidarita zakotvená v křestanském pojetí bližního je tak jedním ze zakotvení novodobé sociální práce, ${ }^{14}$ sama idea sociálního začleňování je pak jedním z jejích pilir̂̃u a úzce také souvisí s ideou kvality života. ${ }^{15}$ A právě mezi silné stránky SQSS je zahrnován dưraz na ochranu práv a důstojnosti klientů a posílení jejich práv. ${ }^{16}$

\section{Lidská práva ve Standardech kvality sociálních služeb}

Jedním ze stěžejních témat SQSS je téma ochrany lidských práv. ${ }^{17}$ Navíc úroveň dodržování práv uživatelů služeb je považována za jeden z hlavních znaků kvality sociální služby. ${ }^{18}$ Zákon o sociálních službách př́imo uvádí, že sociální služby musí být poskytovány v zájmu osob a v náležité kvalitě takovými zpo̊soby, aby bylo vždy důsledně zajištěno dodržování lidských práv a základních svobod osob. ${ }^{19}$

Mezi nejdůležitější lidská práva a svobody, na jejichž dodržování je nutné v sociálních službách obzvláště dbát, je osobní svoboda a svoboda pohybu, právo na ochranu soukromí a nedotknutelnost osoby, dále právo na osobní a rodinný život, právo na důstojné zacházení, právo svobodně se rozhodnout, právo na přiměřené riziko, právo vlastnit majetek, právo na práci a odměnu, právo na vzdělání a právo stěžovat si. ${ }^{20}$

výbor, 2004, s. 9.

9 Srov. zákon č. 108/2006 Sb., o sociálních službách; Dagmar LAHNEROVÁ, Zavádění standardů kvality sociální péče do praxe v zařizeních sociálnî péče pro seniory, diplomová práce, Masarykova univerzita, Fakulta sociálních studií, vedoucí práce Mirka Nečasová, 2008, s. 26. Dostupné na: http://is.muni.cz/th/68209/fss_m/, citováno 9. 11. 2013.

10 Srov. Oldřich MATOUŠEK, Sociální služby: legislativa, ekonomika, plánování, hodnocení, s. 10.

11 Tamtéž.

12 Srov. Jakub DOLEŽEL, Biblické kořeny sociální práce, in: Praktická teologie pro sociální pracouníky, ed. Michael MARTINEK, Praha: JABOK

- Vyšší odborná škola sociálně pedagogická a teologická, 2008, s. 26.

13 Oldřich MATOUŠEK, Sociální služby: legislativa, ekonomika, plánování, hodnocení, s. 10.

14 Srov. Oldřich MATOUŠEK a kol., Encyklopedie sociální práce, s. 147-149.

15 Srov. tamtéž.

16 Srov. Ondřej MÁTL - Milena JABŮRKOVÁ, Kvalita péče o seniory, ř́zení kvality dlouhodobé péče v ČR, Praha: Galén, 2007, s. 44.

17 Srov. př́loha č. 2 vyhlášky č. 505/2006 Sb., kterou se provádějí některá ustanovení zákona o sociálních službách.

18 Srov. Jiří SOBEK, Lidská práva v každodenním životě lidí s mentálním postižením: př́ručka pro zaměstnance sociálních služeb, Praha: Portus Praha, 2010, s. 7 a 29; Srov. Pavel ĆÁMSKÝ - Jan SEMBDNER - Dagmar KRUTILOVÁ, Sociální služby v ČR v teorii a praxi, s. 16-17 a 89.

19 Srov. zákon č. 108/2006 Sb., o sociálních službách, § 2, ods. 2.

20 Srov. Dagmar KRUTILOVÁ, Sociální služby: tvorba a zavádění Standardů kvality poskytovaných sociálních služeb, Tábor: ABENA, 2008, s. 60-66;

Pavel ČÁMSKÝ - Jan SEMBDNER - Dagmar KRUTILOVÁ, Sociální služby v ČR v teorii a praxi, s. 93-103. 
Za jedno z nejdůležitějších lidských práv v kontextu sociálních služeb je považováno právo na svobodné rozhodnutí, s nímž ve své podstatě souvisí téměř všechna další lidská práva a svobody. ${ }^{21} \mathrm{~S}$ možností volby je úzce spjata svoboda jednotlivce. Jeho jednání jako projev vůle bezprostředně souvisí s poznáním skutečnosti. Pokud má být člověk svobodný nejen v rozhodnutí, musí mít přístup k poznání - tedy k relevantním informacím. Svoboda rozhodování se tedy nemůže uskutečnit bez dostatečného přístupu k informacím. ${ }^{22}$ Pro uživatele služeb je právo na svobodné rozhodnutí a jeho dodržování zásadní. Toto právo v praxi znamená možnost přizpůsobovat si průběh sociální služby dle svých představ a službu si takto individualizovat s ohledem na své potřeby, přání a požadavky.

Se svobodným rozhodováním je nedílně spojena také odpovědnost za své rozhodnutí. Jedním $\mathrm{z}$ práv vztahujících se $\mathrm{k}$ této skutečnosti je právo na přiměřené riziko. Mnoho uživatelů služeb - obzvláště u některých typů služeb - má problém s uvědoměním si odpovědnosti za vlastní rozhodnutí, a tudíž i s nesením jeho následků. Je tedy nutné s uživateli pracovat na tom, aby si při rozhodování uvědomovali svou odpovědnost, možná rizika a případné následky. Služba by měla uživatele vést $\mathrm{k}$ tomu, aby se dokázali rozhodovat sami, aby dokázali zhodnotit situaci, rozpoznat možnosti řešení, analyzovat rizika a uvědomit si možné následky. ${ }^{23}$

SQSS společně se zákonem č. 108/2006 Sb. ukládají poskytovateli povinnost zajistit ochranu lidských práv a svobod uživatelů, v současnosti nejčastěji formou vypracování metodiky (pravidel), která se postupně stala prioritou: „Má metodiku, postupuje podle ní.“24 Jednou z nejproblematičtějších oblastí povinnosti tvořit pravidla je pak oddělení teorie (tedy pravidel, postupů a metodik) a praxe (aplikace pravidel), jak potvrzuje např. zjištění Lencové ${ }^{25}$ nebo Musil, který uvádí, že pro organizace může být lákavé pouze administrativní naplňování SQSS bez reálného průmětu do př́istupu ke klientům. ${ }^{26}$ Může se tedy objevit situace, kdy má poskytovatel písemně zpracovaná pravidla a metodiky, které ovšem nejsou aplikované a používané v praxi. Tato situace vzniká nejčastěji tehdy, pokud nejsou metodiky k jednotlivým standardům vypracovávány $\mathrm{v}$ rámci pracovního týmu, ve kterém jsou všichni zaměstnanci organizace, a to včetně pracovníků $\mathrm{v}$ přímé péči, jak potvrdila např. zjištění $\mathrm{z}$ provedených inspekcí v Moravskoslezském kraji především u pobytových služeb. ${ }^{27}$ Tento rozdíl mezi teorií a praxí v oblasti SQSS týkajících se ochrany lidských práv potvrzuje i sonda provedená mezi sociálními pracovníky, jejíž výsledky budou dále popsány.

\section{Jak ochranu práv uživatelů vnímají sociální pracovníci}

V měsících srpnu a řínnu roku 2013 jsme provedly sondu mezi sociálními pracovníky různých typů sociálních služeb v Jihočeském kraji (ambulantní, terénní, pobytové). Záměrně jsme vy-

21 Srov. Dagmar KRUTILOVÁ, Sociální služby: tvorba a zavádění Standardů kvality poskytovaných sociálních služeb, s. 61; Jiří SOBEK, Lidská práva $v$ každodenním životě lidí s mentálním postižením: př́ručka pro zaměstnance sociálních služeb, s. 11 a 61; Pavel ČÁMSKÝ - Jan SEMBDNER - Dagmar KRUTILOVÁ, Sociální služby v ČR v teorii a praxi, s. 95.

22 Srov. Jiří JANKOVSKÝ, Etika pro pomáhající profese, Praha: Triton, 2003, s. 38.

23 Srov. Jiří SOBEK, Lidská práva v každodenním životě lidí s mentálním postižením: př́ručka pro zaměstnance sociálních služeb, s. 31-33.

24 Srov. QUIP - projektová zpráva k 7. lednu 2013, Individuální projekt MPSV: Inovace systému kvality sociálních služeb, 2013 , s. 7.

25 Srov. Drahomíra LENCOVÁ, Význam standardů kvality sociálních služeb ve společnosti Ledax o.p.s., České Budějovice, Jihočeská univerzita, Katedra praktické teologie, bakalářská práce, vedoucí práce Michal Opatrný, 2013, s. 34-54. Dostupné na: https://wstag.jcu.cz/ StagPortletsJSR168/KvalifPraceDownloadServlet?typ=1\&adipidno=25438, citováno 15. 11. 2013. Srov. Libor MUSIL - Olga HUBIKOVÁ - Kateřina KUBALČÍKOVÁ, Kultura poskytování osobních sociálních služeb: Případová studie pečovatelské služby. Zpráva ze druhé fáze výzkumu, Brno: Výzkumný ústav práce a sociálních věcí, 2002, s. 18.

26 Srov. Libor MUSIL - Olga HUBÍKOVÁ - Kateřina KUBALČÍKOVÁ, Kultura poskytování osobních sociálních služeb: Případová studie pečovatelské služby. Zpráva ze druhé fáze výzkumu, Brno: Výzkumný ústav práce a sociálních věcí, 2002, s. 18.

27 Srov. @ Z Zištění z provedených inspekcí kvality sociálních služeb. Moravskoslezský kraj, 2013 (on-line), dostupné na: http://verejnasprava.kr-moravskoslezsky.cz/cz/zjisteni-z-provedenych-inspekci-kvality-socialnich-sluzeb-13555/, citováno dne 15. 11.2013. 
braly služby pro rizikovější cílovou skupinu z hlediska ochrany lidských práv - služby, které mají ve své cílové skupině uživatele s narušenou komunikační schopností (senioři, lidé s mentálním a kombinovaným postižením, lidé s duševním onemocněním), nebot' lidé s narušenou komunikační schopností, at' už trvale nebo dočasně, se vyskytují napříč typologií služeb, a přesto jsou jejich potřeby stále často zanedbávány. ${ }^{28}$ Výběr respondentů jsme provedly metodou snowball sampling s počátkem ve čtyřech organizacích poskytujících sociální služby. Od respondentů jsme získaly další kontakty na organizace a sociální pracovníky. Sběr dat pokračuje i nadále, zde prezentujeme data od sedmi respondentů. Sonda je prováděna formou polostrukturovaného rozhovoru a zjištéuje přístup sociálních pracovníků ke standardům kvality sociálních služeb a vybraným kritériím, které se vztahují k tématice hodnot a ochrany práv a svobod uživatelů.

Kritéria standardů, na něž jsme se v rozhovoru zaměřily, byla zvolena tak, že jsme v Listině základních práv a svobod určily články obsahující práva a hodnoty, které se týkají uživatelů služeb. ${ }^{29}$ Ze SQSS jsme se zaměřily na standardy procedurální, protože jsou nejdůležitější pro nastavení a koncepci organizace a jsou z hlediska ochrany práv uživatelů a mechanismů zajišt'ujících jejich dodržování zásadní. Vybrané články z LZPS jsme potom přiřazovaly k jednotlivým standardům a kritériím, ve kterých se tato práva a hodnoty vyskytovaly (například lidská důstojnost a svoboda rozhodování se určitým způsobem vyskytovala ve všech zvolených standardech a kritériích). Vybraly jsme ty standardy a kritéria, která se dotýkala nejvyššího počtu práv a svobod uživatelů. Po srovnání s Listinou základních lidských práv a svobod jsme pro rozhovor zvolily tyto standardy a kritéria: 1b) uplatňování vlastní vůle uživatelů při řešení své nepříznivé situace; 1d) vnitřní pravidla pro ochranu osob před předsudky a negativním hodnocením; 2 ochrana práv osob; 3 jednání se zájemcem o službu; 4 smlouva o poskytování sociální služby; 5 individuální plánování. V rámci jednotlivých standardů a kritérií jsme se zaměřily na uživatele služeb s narušenou komunikační schopností.

Rozhovory byly realizovány se sociálními pracovníky, kteří měli vzdělání dle zákona o sociálních službách v aktuálním znění. Počet respondentů je sedm, z toho šest sociálních pracovníků s vysokoškolským a jeden s vyšším odborným vzděláním v oboru sociální práce.

V následujícím textu se soustředíme na zjištěné situace nedodržování nebo nerespektování práv uživatelů - situace, při nichž „něco není v pořádku“, které dotazovaní uvedli nebo které vyplynuly z rozhovoru. Následující text $\mathrm{z}$ důvodu rozsahu nezohledňuje situace, kdy dotazovaní uvedli, že k porušování práv uživatelů nedochází. V mnoha př́ipadech pracovníci $\mathrm{v}$ obecné rovině prohlásili, že vše funguje $\mathrm{v}$ pořádku a práva uživatelů jsou dodržována, ale při podrobnějším rozkrytí témat z odpovědí vyplynulo, že ne vše funguje tak, jak by mělo, a že jsou zde jisté mezery v dodržování práv uživatelů. Pouze jedna respondentka př́mo uvedla, že jejich zařízení má nedostatky v dodržování práv uživatelů. Naopak závažné problémy s individuálním plánováním přiznala více než polovina respondentů.

Celkově je ochrana práv uživatelů služeb oslovenými pracovníky v SQSS vnímána jako jejich důležitá součást, ovšem pouze $\mathrm{v}$ obecné rovině. Odpovědi na otázky směřující konkrétněji k jednotlivým standardům či kritériím byly v jednotlivých zařízeních odlišné. Celková shoda respondentů panovala $\mathrm{v}$ tom, že byli přesvědčeni, že jejich zařízení $\mathrm{v}$ maximální možné míře podporuje uživatele při rozhodování a vyjadřování vlastní vưle. V jednom z navštívených za-

28 Srov. Martina MÁTLOVÁ, I my jsme občané! Jak zpř́stupnit úřady i lidem s bariérami v komunikaci, Praha: Společnost pro podporu lidí s mentálním postižením v České republice, 2010, s. 3-15.

29 Jedná se o tyto články: 1, 2, 3 (3), 5, 6, 7, 8 (1), 10 (1,2), 12 (1), 14, 15, 17 (1,2), 30 (1), 31, 35 (1), 36 (1). 
řízení jedna $\mathrm{z}$ autorek $\mathrm{v}$ minulosti plnila odbornou praxi a $\mathrm{z}$ vlastní zkušenosti ví, že jsou zde jisté nedostatky v podpoře při rozhodování a vyjadřování vlastní vưle uživatelů s narušenou komunikační schopností. V zařízení se nepoužívají techniky augmentativní ani alternativní komunikace. Někteří uživatelé s výrazně narušenou komunikační schopností, kteří téměř nedokáží verbálně komunikovat, jsou tak ochuzeni o možnost komunikovat jinou formou, což vnímáme také jako porušení svobody vyhledávat, přijímat a rozšiřovat informace a myšlenky na rovnoprávném základě s ostatními, a to prostřednictvím všech forem komunikace dle vlastní volby, jak tuto svobodu specifikuje Úmluva o právech osob se zdravotním postižením. ${ }^{30}$

Sociálním pracovníkům činilo obtíže vyjmenovat práva související s uplatňováním vlastní vůle uživatele. Dotazovaní přiznávali, že nad tím takto nepřemýšleli a namátkou jmenovali práva, která nejčastěji uplatňují v jejich zařízení, např. právo na soukromí, právo na volbu aktivity, právo na odpočinek. A přitom právě s uplatňováním vlastní vůle uživatele souvisí téměř všechna jeho základní práva, především právo na svobodné rozhodnutí. ${ }^{31}$

Při dotazování na pravidla pro ochranu před předsudky a negativním hodnocením si jedna respondentka uvědomila, že je jejich zařízení vůbec nemá zpracovaná. Ostatní sociální pracovníci byli s využitím pravidel v praxi obecně spokojeni. Hned poté v několika př́ipadech připouštěli, že veřejnost má spíše negativní přístup k uživatelům služby a že se uživatelé v oblastech každodenního života nerealizují jako jejich vrstevníci nevyužívající sociální službu. Tyto skutečnosti jsou známkou toho, že je v oblasti ochrany uživatelů před předsudky a negativním hodnocením prostor pro zlepšení. Čámský přitom pozitivní přístup veřejnosti k uživatelưm služeb a jejich realizaci v oblastech každodenního života srovnatelně s vrstevníky uvádí jako př́klady dobré praxe $\mathrm{v}$ oblasti ochrany klientů před předsudky a negativním hodnocením. ${ }^{32}$

S podobou pravidel pro předcházení situacím, při nichž by mohlo dojít k porušení práv uživatelů, jsou všichni dotazovaní spokojeni, jak s jejich účinností (schopností efektivně zabránit porušování práv uživatelů), tak s jejich využitím v praxi. Jedna z dotazovaných uvádí, že „stačí, aby si na to všichni zaměstnanci zvykli a dodržovali to“. Toto tvrzení je ovšem možné interpretovat i tak, že před zavedením pravidel byla praxe zaměstnanců odlišná, tedy bylo nutné si navykat. Navíc tato odpověd' možná signalizuje i skutečnost, že jsou zmíněná pravidla vytvářena bez zaměstnanců $v$ přímé péči. Opět se tak dostáváme k tématu míry profesionality jednotlivých sociálních pracovníků. Mezi další časté problémy, které sociální pracovníci z pobytových zařízení jmenovali, patří skutečnost, že celkově SQSS nejsou přijímány všemi pracovníky zařízení. Konkrétně uváděli situaci, kdy je zdravotnický personál částečně či zcela ignoruje, protože je považuje za „výmysl“ sociální sekce zařízení. Tato situace je velice problematicky řešitelná a na jejím řešení se musí podílet nejen sociální pracovníci, ale i vedení.

Schopnost komunikace s různými typy uživateli̊ je klíčovou kompetencí dobrého sociálního pracovníka. ${ }^{33}$ Odpovědi na otázky, které byly zaměřeny na komunikaci s lidmi s narušenou komunikační schopností, byly až na jedno zařízení (které mělo tuto oblast dobře propracovanou) rozporuplné a odrážely nejistotu pracovníků v této oblasti. Některá zařízení měla údajně vypracovanou speciální metodiku, avšak odpovědi pracovníků byly vágní a nepřesné. Některá

\footnotetext{
30 Srov. @ Úmluva o právech osob se zdravotním postižením, 13. 12. 2006 (on-line), dostupné na: http://www.mpsv.cz/files/clanky/10774/ umluva_CJ_rev.pdf, citováno dne 29.9. 2013.

31 Srov. Dagmar KRUTILOVÁ, Sociální služby: tvorba a zavádění Standardů kvality poskytovaných sociálních služeb, s. 61; Jiř́i SOBEK, Lidská práva $v$ každodenním životě lidí s mentálním postižením, s. 61; Pavel ČÁMSKÝ - Jan SEMBDNER - Dagmar KRUTILOVÁ, Sociální služby v ČR v teorii a praxi, s. 95.

32 Srov. Pavel ČÁMSKÝ - Jan SEMBDNER - Dagmar KRUTILOVÁ, Sociální služby v ČR v teorii a praxi, s. 86-88.

33 Srov. Oldřich MATOUŠEK a kol., Metody a řizení sociální práce, Praha: Portál, 2008, s. 15; Zuzana HAVRDOVÁ, Kompetence v praxi sociální práce: metodická príručca pro učitele a supervizory v sociální práci, Praha: Osmium, 1999, s. 51.
} 
zařízení si uvědomovala nutnost metodiky, avšak přiznávala, že jsou zatím na samém počátku a vypracování speciálních metodik a komunikačních pomůcek pro komunikaci s uživateli s narušenou komunikační schopností bude ještě dlouho trvat. Využití technik augmentativní a alternativní komunikace je mezi sociálními pracovníky nepříliš časté (přibližně čtvrtina dotazovaných) a osobám s narušenou komunikační schopností není věnována patřičná pozornost a péče, aby se jejich komunikační deficit snížil či vyrovnal. Jeden z dotazovaných uvedl, že se zájemcem s narušenou komunikační schopností jedná stejně jako se zájemcem bez narušené komunikační schopnosti!

Při otázce, zda pracovníci při rozhovoru jednají přímo se zájemcem o službu, nebo s jeho př́ipadným doprovodem (rodina, blízcí), všichni uvedli, že jednají přímo se zájemcem. Z doplňujících otázek v jednom rozhovoru ale vyplynulo, že se často stává, že sociální pracovník se se zájemcem ani osobně nesetká a komunikuje pouze s příbuznými. Zájemce poprvé potká osobně až při nástupu do zařizení. Toto je zřejmé porušení několika základních práv člověka, mimo jiné práva na svobodné rozhodnutí. Fakt, že při položení př́imé otázky respondent odpoví jinak než při položení doplňujících otázek nebo otázky jiné, signalizuje snahu respondentů dělat se v rozhovoru lepšími, prvotní nedůvěru vůči osobě zvenčí, která provádí rozhovor a ptá se na otázky týkající se choulostivých témat (což otázka respektování lidských práv v organizaci jistě je), nebo také výstup možná první hlubší reflexe tématu, kdy rozhovor přinesl možnost přemýšlení a náhledu na téma SQSS, jak potvrzuje i text zmíněný výše. Teprve na základě rozhovoru jedné sociální pracovnici došly některé nedostatky v naplňování SQSS v organizaci. Kdyby realitou byla druhá nabízená varianta, jež by znamenala, že pracovníci si jsou schopni uvědomit skutečný stav ochrany lidských práv uživatelů jejich služby, stačilo by pak už ,jen“ pokračovat v prohlubování reflexe pracovníků v této oblasti a vykonat nápravu.

Individuální plánování služby ve většině zařízení dle vyjádření pracovníků fungovalo dobře či s určitými drobnými problémy, v průběhu rozhovoru nakonec ale více než polovina respondentů přiznala závažné problémy. Jako nejčastější obtíž pracovníci popisovali problém stanovit s uživatelem osobní cíl, dále uváděli rozpaky při povinné revizi plánu. V jednom zařízení však individuální plánování nefungovalo téměř vưbec, pracovníci k němu měli výrazně negativní postoj až odpor. Toto plánování vyžadovalo mnoho zbytečné administrativy a práci strávenou individuálním plánováním a jeho administrativou pracovníci považovali za ztracený čas. Pracovnice uvedla, že uživatelé do plánování většinou nebyli aktivně zapojeni, neměli povědomí o svých osobních cílech ani nepracovali na jejich naplnění. Individuální plány se dle jejích slov v čase nevyvíjely, nebyly vyhodnocovány, revidovány ani měněny. Jak dotazovaná uvedla, celé plánování se odehrávalo spíše na papíre a nikoliv v praxi. V rozhovorech dotazovaní často podotýkali, že by bylo potřebné a vhodné, aby vznikly různé druhy individuálního plánování pro jednotlivé typy služeb. Jedna respondentka zmínila situaci, kdy se pracovníci terénní služby potýkaji při rozvozu obědů s administrativně náročným individuálním plánováním, které klient mnohdy odmítá s tím, že chce jenom přivést oběd. Je však v kompetenci sociálních pracovníků přizpůsobit celý proces individuálního plánování potřebám uživatelů a typu služby. Rovněž pokud se v průběhu individuálního plánování vyskytují časté a závažné obtíže, je na něm, aby celý proces znovu nastavil na míru organizaci a všem zúčastněným osobám. Sociální pracovník jako odborně připravený profesionál by toho měl být schopen, nebot' se jedná hlavně o aplikaci metod a technik sociální práce s jednotlivcem.

\section{Ochrana práv klientů v praxi}

Jak tedy zajistit, aby se teoretická ochrana práv klientů zakotvená ve standardech odehrávala i v praxi? Inspekce kvality sociálních služeb je jistě velice důležitý nástroj, avšak i přesto stále 
v některých zařízeních (obzvláště v těch pobytových) dochází k porušování práv uživatelů, jak uvádí např. veřejný ochránce práv ve své zprávě z návštěv zařízení sociálních služeb pro seniory, kteři jsou jednou z nejcitlivějších skupin uživatelů z hlediska dodržování lidských práv. Ombudsman uvádí: „Mezi prvořadé problémy, kterým by zařízení s touto klientelou mělo věnovat pozornost, patří zejména prevence malnutrice, zajištění práva na soukromí a na svobodu pohybu. “34 Mátl a Jabůrková přináší možné vysvětlení, že obecné nastavení standardů s sebou nepřináší dostatečný tlak na změny. ${ }^{35}$

Při sondě zaměřené na ochranu práv uživatelů v SQSS jedna respondentka sdělila, že několikadenní kontrola na porušování práv klientů zpravidla nepřijde. Na otázku, jak by kromě psaných pravidel zajistila ochranu práv klientů, odpověděla, že by bylo dobré využít třeba studenty, kteří si v zařízení plní svou odbornou praxi, a tedy je navštěvují dlouhodobě. Tito studenti by $\mathrm{v}$ rámci své praxe dali zařízení zpětnou vazbu týkající se ochrany práv uživatelů, která by byla relativně objektivní, protože jsou osobami zvenčí, zároveň kvalifikovanými, nejsou v zaměstnaneckém poměru, ale v zařízení jsou dostatečně dlouhou dobu na to, aby rozeznali porušování práv uživatelů nebo jeho náznaky. Navíc v přítomnosti praktikantů jsou pracovníci otevřenější a méně ostražití než v př́itomnosti inspektorů. Toto řešení je i finančně nenáročné.

Jako další způsob zajištění ochrany práv uživatelů v praxi z provedené sondy mezi sociálními pracovníky v šesti rozhovorech ze sedmi vyplynulo, že tvorby metodik by se měl velice intenzivně účastnit celý pracovní tým při využití rozhovorů, debat, brainstormingu, diskuzí k danému tématu. Důležitá je přítomnost pracovníků přímé péče, kteří znají rizikové situace $\mathrm{z}$ praxe a mohou přispět cennými náměty. Metodiky by neměl tvořit člověk zvenčí, který osobně nepracuje s uživateli, tím méně by se vypracování metodik mělo zadávat soukromé firmě či externímu odborníkovi. Metodika by měla vznikat „z praxe“ a celotýmově, protože jedině tak se zajistí, že pravidla, zásady a postupy v ní obsažené budou opravdu dodržovány a "žity“. Pracovníci se s nimi vnitřně ztotožní a nezůstanou pouze „na papiřre". Metodika, která je výsledkem týmové práce všech pracovníků, je při dodržování práv uživatelů účinnější než metodika vypracovaná odborníkem zvenčí, která není šitá na míru organizaci a nepostihuje všechny oblasti ochrany lidských práv uživatelů, jež jsou pro danou organizaci specifické. Metodika tvořená „od stolu“ tak dle našeho názoru dokládá bud' nekompetentnost sociálních pracovníků v jejich profesi, poněvadž takto vzniklá metodika není v souladu s pojetím člověka v sociální práci, je v rozporu s etickým kodexem sociálních pracovníků a v neposlední řadě signalizuje nezájem sociálních pracovníků o oblast lidských práv uživatelů, nebo dokazuje specifické pojetí sociální práce pouze jako „praktické laické pomoci“, tedy bez nutnosti hlubšího porozumění východiskům a cílům sociální práce. (Sociální pracovníci tedy rezignují na profesní vzdělání, nebo je nedostatek právě v něm?) Na druhou stranu vznik SQSS byl podmíněn právě tendencí zvýšení kvality v sociálních službách. Jistě bychom mohli polemizovat i o dalších vlivech jako motivaci k výkonu povolání apod.

Sonda dle sociálních pracovníků přinesla ještě několik dalších způsobů zajištění ochrany práv uživatelů. Ve třech rozhovorech byl uveden osobnostní profil pracovníka: „Protože někteří lidé se pro sociální práci prostě nehodí,“ jedna respondentka uvedla význam praktického zaškolování nových pracovníků na pracovišti, důležitost absolvování „kolečka“ u zkušenějších kolegů na různých pozicích, kteří budou nového kolegu upozorňovat na možné rizikové si-

34 Srov. Pavel VARVAŘOVSKÝ, Zpráva z návštěvy zařizení: zařízení sociálních služeb pro seniory, Veřejný ochránce práv, 2013, s. 17. Dostupné na: http:// www.ochrance.cz/fileadmin/user_upload/ochrana_osob/2013/zarizeni-socialnich-sluzeb-shrnuti.pdf, citováno dne 25. 9. 2013.

35 Srov. Ondřej MÁTL - Milena JABŮRKOVÁ, Kvalita péče o seniory, s. 45. 
tuace $\mathrm{v}$ oblasti ochrany práv, dávat mu rady, jak $\mathrm{v}$ dané situaci postupovat, a předávat mu cenné zkušenosti z praxe. Podle tří respondentů je samozřejmostí, že se pracovník zevrubně seznámí s metodikami, ale nutný je dle nich i kontakt s praxí, při níž si nový pracovník bude moci vyzkoušet jejich aplikaci v praxi pod dohledem a s podporou kolegů.

Dalším opatřením, které pracovníci nezmínili, ale které považujeme za důležité, je kvalitní supervize a duševní hygiena. Také vzdělávání pracovníků v oblasti SQSS je účinným nástrojem pro zajištění ochrany práv klientů, avšak pouze pokud si z něj pracovník odnáší porozumění a dovednosti, nikoliv jen výklad legislativy, „zaručený návod“ a splnění podmínky vzdělávání. $Z$ realizace rozhovorů vyplynula ještě jedna možnost - diskuze a sdílení zkušeností mezi pracovníky a organizacemi. V jednom zařízení, kde probíhal rozhovor, mají velice dobře vytvořený systém individuálního plánování, který je šitý na míru uživatelům s narušenou komunikační schopností, zatímco v druhém zařízení, kde je sice jiný typ klientů, ale také s narušenou komunikační schopností, se při individuálním plánování potýkají s nemalými problémy, které jsou natolik závažné, že zpơsobují až jeho nefunkčnost. Pokud by si pracovníci těchto zařízení vyměnili své zkušenosti, jistě by i v druhém zařízení došlo k pozitivní změně. Tato vzájemná výměna zkušeností však naráží na překážku - není o ni zájem. Navíc si každé ze zařizení své metodiky chrání a nechce je zveřejňovat, protože je přece stály mnoho hodin práce. Takto situace vypadá ve většině organizací, jak můžeme potvrdit například šestiletou zkušeností se studenty kombinované formy magisterského studia sociální práce, kteří mají v rámci zkouškové práce jednoho předmětu komentovat metodiky svých nebo jiných organizací. Organizace nejsou ochotny metodiky pro tento účel zpřístupnit, ani v anonymizované podobě. Každý rok se najde jen pár organizací, které naopak tuto možnost externí zpětné vazby vítají a vnímají ji jako př́ležitost pro rozvoj. Obáváme se, že to může být vykládáno opět i jako důsledek nedostatečné profesionality sociálních pracovníků vedle dalších přričin jako např. konkurování si mezi organizacemi v "boji“ o klienta, dobrou pověst a dotace na trhu sociálních služeb. Tím se dostáváme k další důležité podmínce pro zabezpečení lidských práv klientů. Sociální práci by měli vykonávat kvalifikovaní sociální pracovníci, mezi jejichž kompetence patři i znalost a ochrana lidských práv, dodržování lidské důstojnosti uživatelů, orientace v legislativě a samozřejmě v etice, nebot' sociální práce je dle Opatrného v jistém slova smyslu „praktickou etikou". ${ }^{36}$

\section{Současná situace a chystané změny}

Posílení ochrany práv uživatelů je cílem probíhajícího projektu MPSV Inovace kvality sociálních služeb. Jedním z jeho principů je přechod od kontroly řízení kvality ke kontrole ochrany práv. ${ }^{37} \mathrm{~V}$ rámci plánované inovace standardů je kladen dưraz na posílení ochrany práv uživatelů, nebot', jak píše Miler, kritizovaná administrativní zátěž spojená s SQSS je nepochopením nutnosti písemně stanovených pravidel jako výsledku procesu, což, jak doplňuje Sýkorová, $\mathrm{v}$ konečném důsledku vede $\mathrm{k}$ formálnímu zavádění standardů. ${ }^{38}$

Dokument Inovace požadavků na kvalitu sociálních služeb, který je výstupem Individuálního projektu MPSV - Inovace systému kvality sociálních služeb, upozorňuje na nedostatky aktuálního znění SQSS z roku 2006 a navrhuje jejich revizi a změnu. V souvislosti s ochranou práv uživatelů upozorňuje na rozpor spočívající v tom, že v současných kritériích standardu č. 2

36 Srov. Michal OPATRNÝ, Sociální práce a teologie, Praha: Vyšehrad, 2013, s. 216.

37 Srov. Dana KOŘíNKOVÁ - Jan STRNAD, Klíčové prvky ochrany práv uživatelů sociálních služeb [pdf], Revize standardů kvality sociálních služeb v kontextu projektu Inovace systému kvality sociálních služeb, konference konaná v Praze dne 20. 6. 2013.

38 Srov. Ondřej MÁTL - Milena JABŮRKOVÁ, Kvalita péče o seniory, s. 46. 
je požadavek na vytváření pravidel pro předcházení situacím, v nichž by mohlo dojít ke stigmatizaci, porušení práv osob nebo ke střetu zájmu, zatímco $\mathrm{v}$ zákoně o sociálních službách se požaduje vytvářet takové podmínky, aby uživatelé mohli naplňovat svá práva, aby rozsah a forma pomoci vždy zachovávaly lidskou důstojnost osob a aby vždy bylo důsledně zajištěno dodržování základních lidských práv a svobod osob. Požadavek na produkování pravidel, při kterém se negativně vymezují nežádoucí situace, má být změněn v souladu se zákonem o sociálních službách na pozitivní formulaci vyzývající k vytváření podmínek pro dodržování lidských práv a respektování lidské důstojnosti. Ve standardu č. 2 se nově objeví podpora při rozhodování, nový způsob kontroly naplňování hodnot a upřesnění pojmu sociální začleňování. Celkově budou standardy více dbát na pozitivní formulaci požadavků a vypustí se nadbytečné požadavky na tvorbu pravidel. ${ }^{39}$

\section{Závěr}

Globálně přistupují sociální pracovníci ke standardům kladně, jejich zavedení považují za přínosné pro svou práci z více důvodů, především vnímají důležitost ochrany lidských práv a svobod uživatelů. Hodnoty, které jsou SQSS chráněny, jsou pracovníky vnímány nikoliv obecně, ale spíše formou konkrétních situací, s kterými přijdou do styku v rámci každodenní praxe, jako je např́ílad hodnota lidské důstojnosti, kterou pracovníci chrání důsledným dodržováním soukromí uživatelů. V oblasti aplikace standardů, které se vztahují $\mathrm{k}$ tématu ochrany lidských práv a svobod uživatelů, jsou ale zjištěny ${ }^{40}$ závažné nedostatky (míra se v různých typech služeb liší), které mohou poukazovat na nedostatečné profesní znalosti a dovednosti sociálních pracovníků a nedodržování etického kodexu. Jak konstatuje Musil a kol., mnozí se zabývají spíše tím, co sami od standardů očekávají, tedy svou pre-koncepcí, než tím, co text standardů požaduje. ${ }^{41} \mathrm{~V}$ důsledku z této skutečnosti vyplývá, že sociální pracovníci jako profesionálové dostatečně nereflektují lidská práva a svobody uživatelů v praxi a nejsou schopni ve své organizaci efektivně zajistit dodržování lidských práv a svobod uživatelů. ${ }^{42}$ Nyní je potřeba ptát se po příčinách, které mohou tkvět $\mathrm{v}$ mnoha oblastech: od způsobu a obsahu vzdělávání sociálních pracovníků přes management konkrétní sociální služby po stav občanské společnosti. ${ }^{43}$

Pokud máme vyhodnotit, nakolik efektivně standardy chrání lidská práva uživatelů, pak musíme odlišit teoretické vypracování metodik (které je dle respondentů na vysoké úrovni) a jejich skutečné využití v praxi. Dle našeho názoru by se standardy měly více zaměřit na samotný proces vzniku metodiky a v souladu s plánovanou inovací SQSS na vytváření podmínek pro dodržování lidských práv a respektování lidské důstojnosti. Rovněž by mělo dojít k zefektivnění systému kontrol ochrany práv uživatelů.

\footnotetext{
39 Srov. Inovace požadavků na kvalitu sociálních služeb. Druhý návrh věcného řešení 30. dubna 2013, Ministerstvo práce a sociálních věcí. Dostupné na: http://www.mpsv.cz/files/clanky/15275/inovace.pdf, citováno dne 25. 9. 2013.

40 Ideálním nástrojem, jak zjistit co nejvíce reálný stav ochrany práv uživatelů, by mohlo být zúčastněné pozorování, jak potvrzuje i jedna $\mathrm{z}$ respondentů.

41 Srov. Ondřej MÁTL - Milena JABŮRKOVÁ, Kvalita péče o seniory, s. 46.

42 Jako hlavní oblast pro rozvoj se vyprofilovalo umožnění komunikace ve srozumitelné formě.

43 Jako neblahý důsledek přístupu veřejnosti k uživatelům služeb a nedostatečné občanské angažovanosti by mohl být interpretován palčivý nedostatek dobrovolníků v sociálních službách, obzvláště ve srovnání se západními zeměmi (srov. EUROPEAN VOLUNTEER CENTRE, Volunteering Infrastructure in Europe, Brussels: CEV - European Volunteer Centre, 2012. Dostupné na: http://www.dobrovolnik.cz/res/ data/021/002564.pdf, citováno dne 12. 12. 2013), kteří by pro rozvoj kvality sociálních služeb mohli být nápomocni, nebot' jeden z nejčastějších argumentů, kterým se odůvodňuje mnoho problematických situací v sociální práci obecně, je nedostatek financí (i pro udržení nebo zajištění dostatečného množství pracovníků pro danou službu) a nízké finanční ohodnocení pracovníků.
} 
Interpretace a př́stup sociálních pracovníků ke standardům kvaliły sociálních služeb z hlediska lidských práv

Abstrakł Text pojednává o problematické implementaci SQSS v praxi sociální práce z hlediska lidských práv. Na základě výsledků sondy bylo zjištěno, že sociální pracovníci vnímají důležitost ochrany lidských práv a svobod uživatelů. $\vee$ oblasti aplikace standardů, které se vztahují k tématu ochrany lidských práv a svobod uživatelů, jsou ale zjištěny nedostatky, které mohou poukazovat na nedostatečné profesní znalosti a dovednosti sociálních pracovníkư a nedodržování etického kodexu. Text prìnáší i popis současné situace a návrhy změny.

Klíčová slova standardy kvality sociálních služeb, lidská práva 